\title{
Don't get the message: the effect of a warning text before visiting a proanorexia website.
}

Citation for published version (APA):

Martijn, C., Smeets, E., Jansen, A. T. M., Hoeymans, N., \& Schoemaker, C. (2009). Don't get the message: the effect of a warning text before visiting a proanorexia website. International Journal of Eating Disorders, 42(2), 139-145. https://doi.org/10.1002/eat.20598

Document status and date:

Published: 01/01/2009

DOI:

10.1002/eat.20598

Document Version:

Publisher's PDF, also known as Version of record

Document license:

Taverne

Please check the document version of this publication:

- A submitted manuscript is the version of the article upon submission and before peer-review. There can be important differences between the submitted version and the official published version of record.

People interested in the research are advised to contact the author for the final version of the publication, or visit the DOI to the publisher's website.

- The final author version and the galley proof are versions of the publication after peer review.

- The final published version features the final layout of the paper including the volume, issue and page numbers.

Link to publication

\footnotetext{
General rights rights.

- You may freely distribute the URL identifying the publication in the public portal. please follow below link for the End User Agreement:

www.umlib.nl/taverne-license

Take down policy

If you believe that this document breaches copyright please contact us at:

repository@maastrichtuniversity.nl

providing details and we will investigate your claim.
}

Copyright and moral rights for the publications made accessible in the public portal are retained by the authors and/or other copyright owners and it is a condition of accessing publications that users recognise and abide by the legal requirements associated with these

- Users may download and print one copy of any publication from the public portal for the purpose of private study or research.

- You may not further distribute the material or use it for any profit-making activity or commercial gain

If the publication is distributed under the terms of Article $25 \mathrm{fa}$ of the Dutch Copyright Act, indicated by the "Taverne" license above, 


\section{Don't Get the Message: The Effect of a Warning Text Before Visiting a Proanorexia Website}

\author{
Carolien Martijn, $\mathrm{PhD}^{1 *}$ \\ Elke Smeets, MSc ${ }^{1}$ \\ Anita Jansen, $\mathrm{PhD}^{1}$ \\ Nancy Hoeymans, PhD $^{2}$ \\ Casper Schoemaker, $\mathrm{PhD}^{2}$
}

\begin{abstract}
Objective: This study examined the effect of the placement of a warning text before visiting proanorexia websites on actual access of these websites.
\end{abstract}

Method: A separate webpage with a warning text aiming at first-time visitors was placed before each proanorexia website hosted by a Dutch Internet provider. During the research period of 1 year, the numbers of hits at the warning webpage were registered together with the numbers of hits at the underlying proanorexia website.

Results: Of the total number of hits registered at the warning webpage, about two-third of the visitors were registered at the underlying proanorexia website. This indicates that about one-third of the visitors did not continue their visit to a proanorexia website after being exposed to the warning text.

Discussion: Placement of a warning text before proanorexia websites appears a promising strategy in holding back potential visitors. (C) 2008 by Wiley Periodicals, Inc.

Keywords: anorexia; forewarning; proanorexia websites; Internet

(Int J Eat Disord 2009; 42:139-145)

\section{Introduction}

"Proanorexia" or "pro-ana" websites are Internet sites commonly run by individuals with an eating disorder. On these websites, participants provide nonjudgmental support for other individuals who are currently engaged in an eating disorder and not in recovery. ${ }^{1}$ On a typical proanorexia website, participants keep a diary (a "blog"), a discussion forum, and upload photo galleries of particularly thin celebrities or obese persons as "thinspiration." Most proanorexia websites have a "Tips and Tricks" section including advice on effective dieting, the use of weight loss drugs and how to prevent detection by family members and professionals when skipping meals or purging. Together, the owners and visitors of pro-ana websites form an on-line community and discuss their food intake, appear-

\footnotetext{
Accepted 23 August 2008

*Correspondence to: Carolien Martijn, Department of Clinical Psychological Science, Faculty of Psychology and Neuroscience, Maastricht University, P.O. Box 616, 6200 MD Maastricht, The Netherlands. E-mail: c.martijn@psychology.unimaas.nl

${ }^{1}$ Department of Clinical Psychological Science, Faculty of Psychology and Neuroscience, Universiteit Maastricht, Maastricht, The Netherlands

${ }^{2}$ Center for Public Health Forecasting, National Institute for Health and the Environment (RIVM), Bilthoven, The Netherlands Published online 23 October 2008 in Wiley InterScience (www.interscience.wiley.com). DOI: 10.1002/eat.20598 (C) 2008 Wiley Periodicals, Inc.
}

ance and weight, and motivate each other to become or stay abnormally underweight.

In popular media, proanorexia websites are portrayed as potentially dangerous, because they may prevent individuals with an eating disorder from discovery and may inspire unsuspecting website visitors to adopt hazardous dieting methods as well. ${ }^{2-5}$ This assumption was moderately evidenced by Harper et al., ${ }^{6}$ who found that undergraduate female students who frequented eating disorder websites had higher levels of body satisfaction and eating disturbance than a comparison group who did not view these sites. Additionally, Csipke and Horne $^{7}$ concluded on the basis of a study among eating-disordered visitors of proanorexia websites that especially "silent browsers" (visitors of sites who do not participate in chatrooms or forums) are vulnerable to a worsening of their symptoms in the absence of beneficial effects of emotional support. Apart from this correlational evidence, we are aware of only one experimental study on the causal nature of exposure to proanorexia sites and the possibility of developing an eating disorder. Bardone-Cone and Cass ${ }^{8}$ randomly assigned female undergraduates to view either a proanorexia website or one of two control websites (on female fashion or home décor). Viewing a proanorexia website led to greater negative affect and lower social selfesteem. Moreover, those who viewed an anorexia website perceived themselves as heavier and reported a greater likelihood of exercising and thinking about their weight in the near future as 
compared with participants who viewed the control websites. These results provide an empirical basis for concern and warrant a search for strategies to diminish the potential harmful effects of proanorexia websites.

In this article, we report a study on the effect of a warning text for potential visitors of proanorexia websites. The goal of our study was to investigate whether a warning text would prevent potential visitors to access proanorexia websites. For this goal, a warning text was developed and placed before each proanorexia website hosted by "punt.nl," the biggest provider for web logs in the Netherlands. The warning text was explicitly written for first-time visitors of proanorexia websites and not for regular visitors, because we did not expect the latter category to be affected by any warning whatsoever. The warning text aimed at potential visitors who have little knowledge about anorexia or pro-ana; young girls who are dieting, and who are looking for support and useful advice and tips. The distinction between experienced, regular visitors and inexperienced, and relatively ignorant visitors is supported by the findings of Fox et al., ${ }^{9}$ who analyzed a proana community and identified a controversy between "true ana's" and young visitors "who are looking for a quick fix weight loss solution" (p. 957). It is especially the second category that we wished to reach with our warning message to counterbalance the impression that pro-ana is a healthy lifestyle. The most important aim of the warning message was that new visitors would refrain from visiting a proanorexia website after being exposed to the warning text.

\section{Wanted and Unwanted Effects of Warning Messages}

Past research on the effects of warnings has focused on two different questions regarding the attractiveness of and the resistance against a particular content preceded by a warning. The first question addresses so-called backfire or boomerang effects and focuses on unwanted by-effects of warnings, namely that a content appears more attractive and interesting after a warning. The reason for this concern is based on reactance theory, which predicts that people will experience inner protest or psychological reactance when they believe their freedom to engage in a particular behavior is threatened. ${ }^{10-13}$ Thus, if a forewarning is perceived as a threat to one's free choice to visit a proanorexia website, the motivation to access the website may increase instead of decrease. A series of experiments by Bushman and Stack ${ }^{14}$ showed that warning labels for violent television programs increased viewers' interest in violent programs. However, when a warning label was formulated in an informative manner, the label did not produce reactance and a greater desire to watch the program. This implies that a preceding text placed before a proanorexia website should be formulated as information and should avoid an impression of censorship.

A second question addresses whether or not warning texts foster subsequent resistance against a particular content. In this study, we did not expect all or even the majority of first-time visitors to refrain from visiting a proanorexia website after reading a warning text. Therefore, it is important to phrase and design a warning text in such a manner that it helps a visitor to resist the possible attraction of a pro-ana life style and to refute the ana rules and regulations. Unfortunately, some studies on resistance against persuasive messages preceded by warnings reported more resistance, ${ }^{15}$ whereas other studies observed reduced resistance ${ }^{16}$ of subsequent persuasive appeals. Two extensive reviews on the effects of warning on subsequent resistance have explained such contradictory findings by means of the personal relevance of the issue that is warned for. ${ }^{17,18}$ When an issue is of little personal relevance for an individual, a warning will have no or small effects, or may even result in the opposite effects. However, when a persuasive message targets on issues and beliefs that are personally important and relevant to individuals, forewarning may create greater resistance. When personally relevant, a warning may trigger and stimulate individuals to come up with their own reservations and counterarguments.

To summarize, an important lesson from past research is that warnings should be construed with great care. If first-time visitors believe that a warning aims at thwarting their freedom to access a proanorexia website, the effect of the warning is likely to increase the interest in or the potential influence of a proanorexia website.

\section{The Current Study}

We developed a warning text with an emphasis on information (i.e., what is anorexia, what is pro-ana, references to other web sites with information about anorexia). Although the warning text addressed the negative consequences of anorexia and an anorectic diet, these aspects were described 
as factual as possible. Moreover, it was not our aim to frighten the readers, because past research showed that warning messages that induce fear are generally ineffective. ${ }^{19}$ Also, because warnings that included authoritative or expert sources produced mixed evidence or counterproductive results ${ }^{14}$ in terms of interest for the content, we decided for a warning without reference to a source. Given the anonymity and lack of knowledge about the background of those who decide to visit a proanorexia website, it is of course impossible to establish whether anorexia or proanorexia represents a personally relevant issue to visitors. There may be numerous reasons why someone intends to visit a proanorexia site, such as curiosity, because of media attention, because the issue is personal relevant, and it may happen even by "accident." It was beyond the scope of our study to establish whether a warning may lead to subsequent resistance for the persuasive appeal of a proanorexia website. However, we incorporated elements in our warning text with the goal to stimulate readers to produce their own counterarguments and included links to other informative websites that might help them to come up with their own considerations.

The warning text was placed before each existing and new proanorexia website hosted by the Internet provider who cooperated in our study. Subsequently, we monitored for a period of 1 year whether potential visitors of a proanorexia website hosted by the provider did or did not access a particular website after being exposed to our warning text. Bearing the earlier findings on warning messages in mind, our expectations about the effect of our warning text was modest. More specifically, we expected a $5-10 \%$ reduction in visits to proanorexia websites.

\section{Method}

\section{Warning Message}

The warning text was developed by the last author (CS) after consultation of a forum of health psychologists, therapists specialized in the treatment of eating disorders, and an exanorexia patient. The main goal of the text was to warn potential visitors of a proanorexia website of its contents and to counterpoise the impression that pro-ana is a healthy life style instead of a lifethreatening, psychiatric disorder. The text did not aim at regular visitors of proanorexia websites with or without an eating disorder because we did not expect them to change their behavior after reading our message. Rather, the warning text was written for new visitors who know nothing or very little about anorexia or proana, e.g., young girls who are dieting and who search the Internet for dieting tips and support. The warning text was placed on a different page that was loaded automatically whenever a visitor tried to access a proanorexia website (see Fig. 1 for an impression of the warning internet page).

\section{Registration of Visits to the Warning Website and Proanorexia Websites}

The warning internet page was operational from October 1, 2006, onward, and it was placed before each proanorexia websites hosted by the provider. When a new website was discovered, the warning internet page was placed before the website. If a website was removed by its owner, the warning page automatically disappeared as well (before that particular website). To monitor the effect of the warning, automatic counters were installed at the warning page and at the underlying proanorexia website. The results reported in the presented article encompass the period between October 1, 2006, and September 30,2007 , i.e., exactly 1 year.

\section{Results}

\section{Warning Message and Subsequent Visits to Proanorexia Websites}

Within the research period between October 2006 and September 2007, we identified a total number of 246 different proanorexia websites; not all websites were online during the entire research period. Forty-five websites $(18.3 \%)$ were online between 6 months and 1 year, 55 websites (22.4\%) between 3 and 6 months, 81 websites (32.9\%) between 1 and 3 months, and 65 websites (26.4\%) existed less than 1 month. This data should be interpreted with care because of the possibility that owners may close a website and continue under a different website name.

During the first month of the research period (October 2006), a total of 18 proanorexia websites were detected by the provider. Their number rapidly increased; a year later (October 2007), the provider identified no less than 193 websites (see Table 1). In the 12 months of the research period, we counted a total number of 537,964 visits at the warning website. On the average, these were 44,830 visits per month (SD 12767.2) with a range between 28,452 (December 2006) and 65,619 (June 2007) visits. 
FIGURE 1. Impression of warning text before proanorexia websites hosted by Dutch provider punt.nl (http//: waarschuwingstekst.punt.nl//, translated from Dutch).

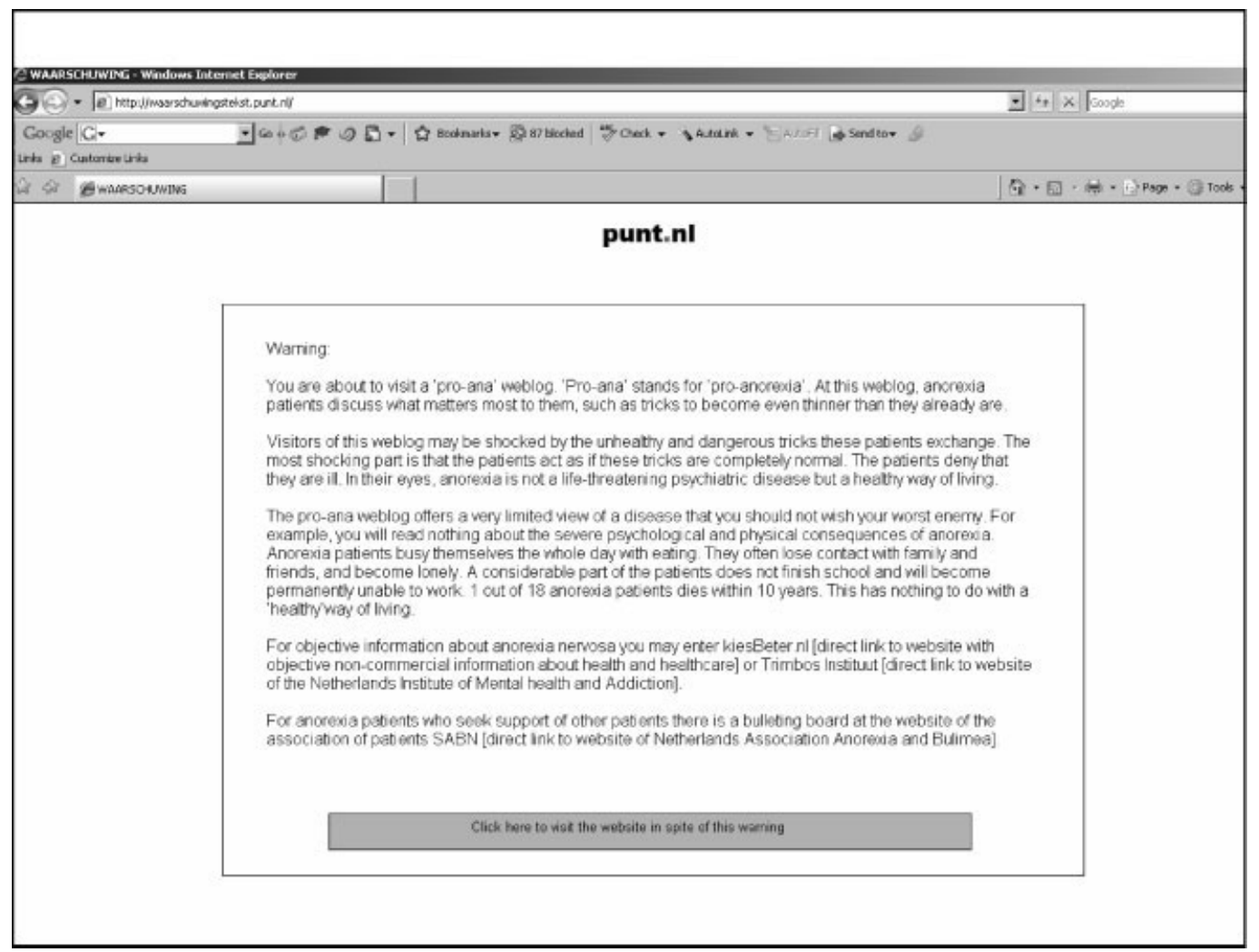

TABLE 1. Proanorexia websites identified per month, hits at warning website, hits at proanorexia websites, and number of hits to warning website only

\begin{tabular}{|c|c|c|c|c|}
\hline & Websites & $\begin{array}{l}\text { Hits at warning } \\
\text { website (a) }\end{array}$ & $\begin{array}{l}\text { Hits at proanorexia } \\
\text { website (b) }\end{array}$ & $\begin{array}{c}\text { Hits warning website } \\
\text { only }(a-b)\end{array}$ \\
\hline Period & $n$ & Total & Total (\%) & Total (\%) \\
\hline October 2006 & 17 & 26,200 & 16,493 (62.1) & $9,727(37.9)$ \\
\hline November 2006 & 22 & 31,734 & 13,159 (41.5) & $18,575(58.5)$ \\
\hline December 2006 & 21 & 28,452 & 11,446 (40.2) & $17,006(59.8)$ \\
\hline January 2007 & 31 & 38,278 & $18,847(49.2)$ & $19,431(50.8)$ \\
\hline February 2007 & 47 & 39,622 & $26,253(66.3)$ & $13,369(32.7)$ \\
\hline March 2007 & 90 & 45,849 & $31,841(69.4)$ & $14,008(30.6)$ \\
\hline April 2007 & 91 & 39,660 & $30,933(78.0)$ & $8,727(22.0)$ \\
\hline May 2007 & 107 & 56,802 & 43,430 (76.5) & $13,372(23.5)$ \\
\hline June 2007 & 154 & 65,619 & $49,026(74.8)$ & $16,593(25.2)$ \\
\hline July 2007 & 175 & 52,994 & 36,397 (68.7) & $16,547(31.3)$ \\
\hline August 2007 & 185 & 55,933 & $39,257(70.2)$ & $16,679(29.8)$ \\
\hline September 2007 & 193 & 56,851 & $40,355(71.0)$ & $16,469(29.0)$ \\
\hline Total & & 537,964 & $357,437(66.4)$ & $180,527(33.6)$ \\
\hline
\end{tabular}

Of the total number of 537,964 visits to the warning website, $357,437(66.4 \%)$ visits were registered to the underlying proanorexia website. Thus, about one-third of the visitors (33.6\%) did not continue their visit and stopped after being exposed to the warning text. Table 1 presents the number of hits to the warning website and the number of hits to the underlying proanorexia websites per month within the research period. The warning appeared to have the most effect in November and December 2006, in which $58.5 \%$ and $59.8 \%$, respectively, did not proceed their visit to a proanorexia website after exposure to the warning website, and least effective in April and May 2007, in which 22\% and $23.5 \%$ did not continue their visit. The reason for this is not immediately clear, although we suspect that especially the decreasing effect in April and May 2007 is related to attention in the media for 
proanorexia websites in The Netherlands. To summarize, apart from an increase of the hit rate to proanorexia websites, in the first 4 months about half of the visitors who were presented with the warning website did not continue their website to the intended proanorexia website. In the months to follow, the effectiveness of the website tended to decrease and to stabilize. About a quarter to onethird of visitors was discouraged to continue their visit in the remaining 8 months of the research period.

Starting from January 1, 2007, it was registered whether or not a visitor of the warning text browsed the warning website earlier. This was examined by means of the presence of so-called cookies. These are small text files send by a Web server to a Web browser (visitor) that are stored as a text files on the visitor's computer. In the period from January 1 to September 30, 2007, 65.9\% of the visitors who hit our warning website did not have a cookie on their computer from a prior visit to the warning website. From this data it can be derived that about two-third of new visitors of proanorexia websites did not visit a proanorexia website (hosted by this particular provider) before. However, this result should be interpreted with great care. It is possible that a web visit was incorrectly classified as a unique visit because (a) a browser removed cookies from a computer and (b) a browser used different computers to access proanorexia websites.

It was also checked whether the placement of a warning text resulted in the unwanted effect of an increase in the number of website visitors. At October 1, 2006, the start of the research period, the provider identified 11 proanorexia websites, and the automatic counter was attached to these and all following websites. Also, before each proanorexia website, except for two, the warning text was placed. For these two websites, the warning text was placed at later moments in time to detect a possible increase of visitors after placement of the warning text. The frequency of visits to the websites temporarily increased during the first weeks after placement of the warning texts. In the weeks to follow, frequency of web visits reduced back to or under baseline (i.e., the frequency before placement of the warning text).

A total of 15,016 visits were registered to the three noncommercial, informative websites that were recommended in the warning text. The preference for the three websites was about equal $(37.5,30.6$, and $31.8 \%$ of visits to each of the three respective websites).

\section{Discussion}

To our knowledge, this is the first study that measures the effect of a warning text placed before proanorexia websites on actual browsing behavior. The study was conducted in cooperation with one of the biggest weblog providers in The Netherlands. A first remarkable result is the number of (intended) visits to proanorexia sites. Within a year's time, more than half a million visits to the website with the warning text were registered. Another notable result is the increase in the number of proanorexia websites; in a year, the number of proanorexia websites hosted by one single provider increased more than 10-fold. Also, the number of (intended) visits to proanorexia websites per month more than doubled within the research period.

As the evidence for the effectiveness of forewarnings is mixed, ${ }^{14,18}$ our expectation of the effect of the warning text was not overly optimistic. We hoped that a carefully constructed message with an emphasis on information would decrease the number of actual visits by $5-10 \%$. However, the warning text was more successful than expected; about one-third of the intended visits to a proanorexia website were not translated in an actual visit after exposure to the warning website. The majority of visits to the warning website were made from computers that probably did not browse the website before (as derived from the absence of cookies). Although this result should be interpreted with great care, it is likely that those who did not carry out their intended visit were mostly first-time visitors (the target group of the warning intervention). It seems unlikely that regular visitors were held back by a warning text.

Noteworthy is the considerable fluctuation in the number of visits to the warning websites and the proportion of actual visits to underlying proanorexia websites per month. It is possible that sudden increases in visits were related to media attention. Overall, the largest effect of the warning website was observed in the months directly after placement; more than half of the visitors refrained from visiting after being exposed to a warning website to a proanorexia website. In the months to follow, the success of the warning website stabilized around $30 \%$ less visits after exposure to the warning website.

\section{Limitations of This Study and Future Research}

Notwithstanding the impression that the effects of a warning text placed before proanorexia websites 
appears a promising strategy to hold back potential visitors, this study has a number of limitations. First, the number of visits before placement of the warning text could be registered reliably for two websites only. Although the results of the effect of the warning text for these two websites seem promising, a future study should include premeasurements of more websites to establish the effect of warning more systematically. A second limitation is that, although the warning appeared to ward off potential visitors, it is difficult to establish the key ingredient(s) of this effect. It is possible that the mere presence of a barrier (i.e., a website before the particular website one intends to visit) discourages browsers to continue, irrespective of its content. For a better understanding of the possible effectiveness of internet warning texts, it needs to be ascertained how the form and content of warning texts are optimally designed and a control group is needed. For example, does a separate web page work better than a pop-up, what is the optimal length for a warning text, is an informative content indeed more effective than an emphasis on the potentially dangerous content of an underlying website, and so forth.

In future research, such questions should be studied by means of controlled experiments in which, for example, different forms and contents of warning texts that are randomly paired to proanorexia websites and control websites are compared with a no warning text control condition. Moreover, to design an optimal warning text, more knowledge is needed about the motivation of potential visitors. To acquire such knowledge, brief on-line surveys could be linked to the warning website with questions about visitors' background and motivation. Although, the warning text stopped about one-third visits, it is also of interest to find out more about the two-third that ignored the warning, especially about those who visit a proanorexia website for the first time. Important to know is whether the presence of a warning text helped first time visitors to browse a proanorexia website more critically than without a warning. In other words, may a warning text forearm a visitor and subsequently induce more resistance to the possible influence of a proanorexia website?

\section{Conclusion}

Many have expressed their worries about the existence and growth of proanorexia website and their potential harmful effects on naïve viewers. The simplest solution seems to ban proanorexia sites. In April 2008, the French National Assembly adopted a bill that prohibits anorexia-promoting publications, including proanorexia websites. Anyone who "incites" extreme thinness on websites, magazines or in advertisements risks a punishment of up to 3 years imprisonment and 30.000 Euros (about 47.500 dollars). Earlier, in 2002, the American Internet provider Yahoo decided to close all proanorexia websites. Unfortunately, the effect of the closure was only temporal; websites moved to other providers or reappeared under a different name. As the Academy for Eating Disorders stated in their standpoint on proanorexia websites in 2002, "The Academy of Eating Disorders is committed to using our resources and collective influence to communicate that eating disorders are serious illnesses that can have devastating influences for those who suffer from them." ${ }^{20}$ Our first investigation of a warning text implies that the placement of such texts is a promising strategy to decrease the actual number of visits to potential harmful websites without the need of censorship. To establish and understand the possible outcome of warnings placed before proanorexia websites, more research is needed to identify the crucial elements of an effective warning text.

\section{References}

1. Dias K. The ana sanctuary: Women's pro-anorexia narratives in cyberspace. J Int Womens Stud 2003;4:31-45.

2. Reaves J. Anorexia goes high tec. Time, July 2001. Available at: http://www.time.com/time/health/article/0,8599,169660,00.html. Accessed on February 26, 2008.

3. Song S. Starvation on the web. Time, July 2005. Available at: http://www.time.com/time/magazine/article/0,9171,10813701,00.html. Accessed on February 26, 2008.

4. Williams A. Before the spring break, the anorectic challenge. New York Times, April 2, 2006. Available at: http://www. nytimes.com/2006/04/02/fashion/sundaystyles/. Accessed on February 26, 2008.

5. Asthana A. Danger of the websites that promote anorexia. The Observer, January 2007. Available at: http://www.guardian.co. uk/technology/2007/jan/07/news.medicineandhealth. Accessed on February 26, 2008.

6. Harper K, Sperry S, Thompson JK. Viewership of pro-eating disorder websites: association with body image and eating disturbances. Int J Eat Disord 2008;41:92-95.

7. Csipke E, Horne O. Pro-eating disorder websites: Users' opinions. Eur Eat Disord Rev 2007;15:96-206.

8. Bardone-Cone AM, Cass KM. What does viewing a pro-anorexia website do? An experimental examination of website exposure and moderating effects. Int J Eat Disord 2006;40:537-548.

9. Fox N, Ward K, O'Rourke A. Pro-anorexia, weight-loss drugs and the internet: An 'anti-recovery' explanatory model of anorexia. Sociol Health IIIn 2005;27:944-971. 
10. Brehm JW. A Theory of Psychological Reactance. New York: Academic Press, 1966.

11. Brehm JW. Responses to Loss of Freedom: A Theory of Psychological Reactance. Morristown, NJ: General Learning Press, 1972.

12. Brehm SS, Brehm JW. Psychological Reactance. New York: Wiley, 1981.

13. Wicklund RA. Freedom and Reactance. Potomac, MD: Erlbaum, 1974.

14. Bushman BJ, Stack AD. Forbidden fruit versus tainted fruit: Effects of warning labels on attraction of television violence. J Exp Psychol Appl 1996;2:207-226.

15. Freedman JL, Sears DO. Warning, distraction, and resistance to influence. J Pers Soc Psychol 1965;1:62-266.
16. McGuire WJ, Millman S. Anticipatory belief lowering following forewarning of a persuasive attack. J Pers Soc Psychol 1996;2:471-479.

17. Petty RE, Cacioppo JT. Effects of forewarning of persuasive intent and involvement on cognitive responses and persuasion. Pers Soc Psychol B 1979;5:173-176.

18. Wood W, Quinn JM. Forewarned and forearmed? Two metaanalytic syntheses of forewarnings of influence appeals. Psychol B 2003;129:199-138.

19. Witte K, Allen M. A meta-analysis of fear appeals: Implications for effective public health campaigns. Health Educ Behav 2000;27:591-615.

20. Academy for Eating Disorders. AED position statement on pro-anorexia web sites. Available at: www.aedweb.org/policy/ pro-anorexia_sites.cfm. Accessed on February 26, 2008. 